\title{
THE EFFECT PAYMENT METHODS AND SERVICES ON THE SATISFACTION BPJS HEALTH MEMBERS SOUTH TANGERANG
}

\author{
Muhammad Sopiyana \\ Universitas Pamulang \\ sopiyana1989@gmail.com
}

\begin{abstract}
As a form of good service is to see how important the implementation of good service standards in a government administration and to see if the form of public service has been in accordance with government policy which in this case is bpjs health office, especially with regard to health welfare services for the People of Indonesia especially in South Tangerang, in its implementation is still not maximal, namely by looking at some things related to the effectiveness of the community namely by looking at how the apparatus or implementing officers in serving the community, how are the regulations on the method of payment of mandatory dues of BPJS Health members, how bpjs kesehatan network activities are carried out in South Tangerang, and how the public can enjoy the service so that the community is satisfied by BPJS Health services in South Tangerang The research method is a quantitative method that emphasizes the aspect of measurement objectively towards social phenomena that are the people of BPJS health services in South Tangerang. The data collection method uses primary data. Tekning sampling used is a conviniens sample technique with respondents who are members of BPJS south tangerang city. The analysis used in this study is a multiple linear regression analysis that is with the calculation of spss through validity testing, reality testing, classic assumption testing, and multiple linear regression analysis. The results of this research show that (1) Payment methods have a positive effect on the satisfaction of members of BPJS Health, (2) BPJS Health services positively affect the satisfaction of BPJS Health members, (3) Payment methods and services BPJS Shared health the same affects the satisfaction of BPJS healthcare members.
\end{abstract}

Keywords: Payment Methods, Service, And Customer Satisfaction

\section{INTRODUCTION}

Public service can be defined as any form of service, both in the form of public goods and public services which in principle become the responsibility and implemented by government agencies in the center, in the area, and in the environment of state-owned enterprises or district-owned enterprises, in order to 
fulfill the needs of the community and in order to implement the provisions of legislation. Pasalong (2010:128). Public service based on the decree of the Minister of administrative reform No.: 63/KEP/M. PAN/7/2003 as follows. In the life of state, the Government has the function of providing public services needed by the community, especially to meet the needs of society in various aspects of life, and can develop its ability and creativity in achieving common objectives. Therefore, the Government is obliged and responsible in providing good and professional public services. The state is an agency or authority governing or controlling common issues in the name of society. Regional autonomy is the right, authority, and obligation of an autonomous region to regulate and manage the affairs of government and the interests of local communities in accordance with statutory regulations. The law on regional autonomy has given proportionately wider, tangible and responsible authority to the region to govern the division, utilization of resources, and the authority to establish policies that are specific and general in accordance with the principles of democratization, the improvement of community participation, equality and fairness and the potential and diversity of each region. One of the most important indikiators in the success of regional autonomy is to implement good, transparent, accountable and professional public service policy Mahmudi (2010:223)

Therefore, the Government is obliged and responsible in providing good and professional public services. Seeing the current nation's condition, the demand for public service will always increase both in terms of quality or in terms of quantity, in line with the increasing number of population, increased welfare level and the growing development of excellent service area by utilizing information technology is a condition of the implementation of good government and clean government and the realization of the inter organization accountability has become a competition for the improvement of service between institutions and as a guideline in the development has been governed in the instruction of the President of the Republic of Indonesia No. 3 of 2003 about national policies and strategies for E-Government development.

The right Momentum as a public service improvement is a driver for government agencies in West Java to improve services by advancing the dimensions of service quality that is easier, faster and transparent. This concept is implemented in a healthoriented public service office called BPJS Healthcare, BPJS Health is a public office that serves the community about welfare in the health sector. BPJS Office is serving the health insurance that is regulated by the central Government that is authorized by the local government, the task of this BPJS health is the management of health fund both from the general public, the private workforce, civil servants, etc.

The world of information technology that is always growing in real time mainly among the banking and the company. It is a reference to develop an improved service improvement to provide easy access, simplicity, clarity, time assurance, data accuracy to taxpayers. Griffin (2003:344). The improvement of the service by utilizing the information technology is also accompanied by a legal basis that holds it or still pay attention to the corridors of the rules that exist in the joint instruction of the Minister of Security, Interior Minister and Finance Minister on the implementation of the administration system. This form of public service is included in the Administrative Services group which is a service that generates various forms of official documents that are needed by the public. 
With the existence of network services in each office with BPJS Health can provide services to the community or taxpayers. As a good form of service is to see how important the application of good standards of service in a government administration. To see if the form of public service has been in accordance with government policy that in this case is the office of BPJS Health. Especially related to the health welfare services for Indonesian people in South Tangerang. The implementation is still not maximal. It is by looking at some things related to the effectiveness by looking at how the apparatus or implementing officers in serving the community.

How rules regarding the payment method of compulsory dues member BPJS health. How to conduct BPJS Health network activities in South Tangerang. As well as how people can enjoy the service so that the community is satisfied by BPJS Health service in South Tangerang. Based on the background explanation above then the author has a purpose to dig the information that is in the casue, including: To test the influence of payment methods BPJS Health to the satisfaction of BPJS members health. (1). To test the influence of BPJS health payment method on the satisfaction of BPJS members health. (2). To test the influence of whether payment methods and good service affect the satisfaction of BPJS Health members in South Tangerang. (3). To test the influence of whether payment methods and good service affect the satisfaction of BPJS Health members in South Tangerang.

\section{LITERATURE REVIEW}

\subsection{Understanding BPJS Health}

The Social Security administering agency or BPJS is an institution established to conduct social security programs in Indonesia under Act No. 40 year 2004 and Law number 24 year 2011. According to Law No. 40 year 2004 on national Social Security system, BPJS is a non-profit legal entity.

Based on Law No. 24 of year 2011, BPJS will replace a number of social security institutions in Indonesia that is health insurance coverage institution PT Askes Indonesia become BPJS Kesehatan and Social Security institution of PT Jamsostek to BPJS employment. Transformation of PT Askes and PT Jamsostek become BPJS done gradually. At the beginning of 2014, PT Askes will become BPJS Healthcare, hereinafter 2015 turn of PT Jamsostek to BPJS employment. Act. Kemenkes, 2014:26)

\subsection{Public services}

Service is the essential main task of the apparatus, as a servant of the state and a public servant. This task has been clearly outlined in the opening of the Constitution 1945 the fourth paragraph, which includes 4 (four) aspects of the basic service of apparatus to the community, namely protecting the whole nation of Indonesia and all the blood in Indonesia, advancing the general welfare, educate the life of the nation and implement world order based on independence, eternal peace and social justice (Moenir H.A.S. Hanandjoeddin. 1992:16). And further explained in the Decree of the Minister of Administrative Reform No. 63 year 2003 that outlines the general guidelines for Public service implementation

Service as a process of fulfilling the needs through the activities of others in the event, is a concept that is always actual in various aspects of institutional. It is not only on business organizations, but has expanded more broadly on government organizational order (Sinambela, 2006:42-43).

Today people's lives experience many changes as a result of progress that has 
been achieved in the previous development process and rapid progress in science and technology. The change that can be felt today is the occurrence of changes in the mindset of society in an increasingly critical direction. It is possible, because more and more days people are increasingly intelligent and increasingly understand their rights and obligations as citizens. The condition of the community thus demands the presence of governments who are able to fulfill various demands of necessity in all aspects of their lives, especially in obtaining the good service from the government.

\subsection{Customer Satisfaction}

Today's attention to satisfaction as well as customer dissatisfaction has been increasingly great because basically the goal of the company or educational institution is to create a sense of satisfaction with the customer. The higher the level of customer satisfaction, it will bring a bigger profit for the company, because the customer will make a repurchase to the company product. However, when customer perceived satisfaction level is small, it is possible that the customer will move to the competitor product.

According to Kotler, contentment is the level of one's feelings after comparing the performance or results she felt compared to her expectations. Whereas Tse and Wilton in Lupiyoado satisfaction or the dissatisfaction of customers is the customer's response to the evaluation of discrepancies (disconfirmation) perceived between previous expectations and the actual performance of the product that is felt after its use. Wilkie defines it as an emotional response to the evaluation of the consumption experience of a product or service. (Engel, 2000:120) states that customer satisfaction is a after-sales evaluation where the chosen alternatives are at least equal or exceed customer expectations, whereas dissatisfaction arises when the outcome does not meet expectations. Customer satisfaction of a product or service, is actually something that is difficult to get if the service company or industry does not really understand what the customer expects. For a product or service of the same quality, it can provide a different level of satisfaction for customers. Therefore, a company should always pay attention to the quality of products and services provided to customers. Customer satisfaction is a customer's response to a discrepancy between the previous level of interest and the actual performance it felt after usage. Customer satisfaction is influenced by the perception of service quality, product quality, price and factors that are personal and of a instantaneous situation.

\section{RESEARCH METHOD}

In this study, research using quantitative research methods is a method that emphasizes the objective aspect of measuring objectively towards social phenomena. To be able to perform measurements, every social phenomenon is defined into several components of problems, variables and indicators. Each specified variable is measured by giving the symbol - different symbol numbers according to the category of information relating to the variable. By using symbols of the figure, the quantitative calculation technique of mathematics can be done so that it can produce a conclusion that is common in a parameter. The main purpose of this methodology is to explain a problem but generate generalization. Generalization is a fact of truth that occurs in a reality of a problem that is expected to occur in a certain population.

Then the researcher using the survey method is a method that is often used to 
obtain information in the form of opinion or opinion of the people who are directly related to what they want to observe. The main purpose of this type of research is to know the general description of the population through samples of some people

\subsection{Data collection methods}

The data collection methods used in this study are secondary data. Secondary data is the primary data that has been processed further and presented either by the primary data collector or by another party. This secondary Data is used by the researchers for further processing (Husein Umar, 2008:100). Secondary data sources to support this research are derived from the study of libraries and documentation regarding the related subject in the study.

\subsubsection{Documentation}

Data collection is done by quoting directly the data that has been obtained from the office BPJS Tangerag Selatan.

\subsubsection{Library Studies}

Data collection aimed at knowing the theories of the variables examined in the libraries (Sources: readings, books, references, journals) and to know about previous research has been conducted on the variables that will be examined to support the research. Based on the explanation above, the method used is the primary data that is obtained by researchers from questionnaires that are spread by researchers, then in exra with data secondary by retrieving data already in the office of Bpjs Tangerag Selatan.

\section{2. .Sample Collection Techniques}

\subsubsection{Population}

The study used the population is a generalization area consisting of objects or subjects that have certain qualities and characteristics set by researchers to learn and then withdrawn in conclusion. The population referred to here is a member of BPJS compulsory participants in South Tangerag.

\subsubsection{Samples}

Samples are part of the number and characteristics owned by the population. In other words the sample is a representative of the population used for research, which then results in generalization. The samples taken in this study were 80 people taken with certain criteria.

The sampling method uses nonprobability purposive sampling, where samples taken from the population are determined based on the criteria set out in this study. Therefore, the samples in this research are mandatory to pay BPJS and office employees of BPJS services with analysis accompanied by supporting documents.

\subsection{Data Analysis Techniques}

The analytical methods used in this study are multiple linear regression analyses. This method aims to describe the nature of something that is underway at the time of research and examine the causes of a particular symptom of Travers (1978) in (Husein Umar, 2008:81). In other words, this analysis is about to measure the alleged factors for a bound variable. The analysis systematics used in this study were:

\subsubsection{T test (partial test \\ 3.3.2. Test F (Model feasibility test)}

\subsection{Hypothesis Model}

This The study is complete with conceptual frame modeling provided by the researchers so that in understanding the relationship with variables is easier to understand, with conceptual frameworks also easier to see hypotheses. 


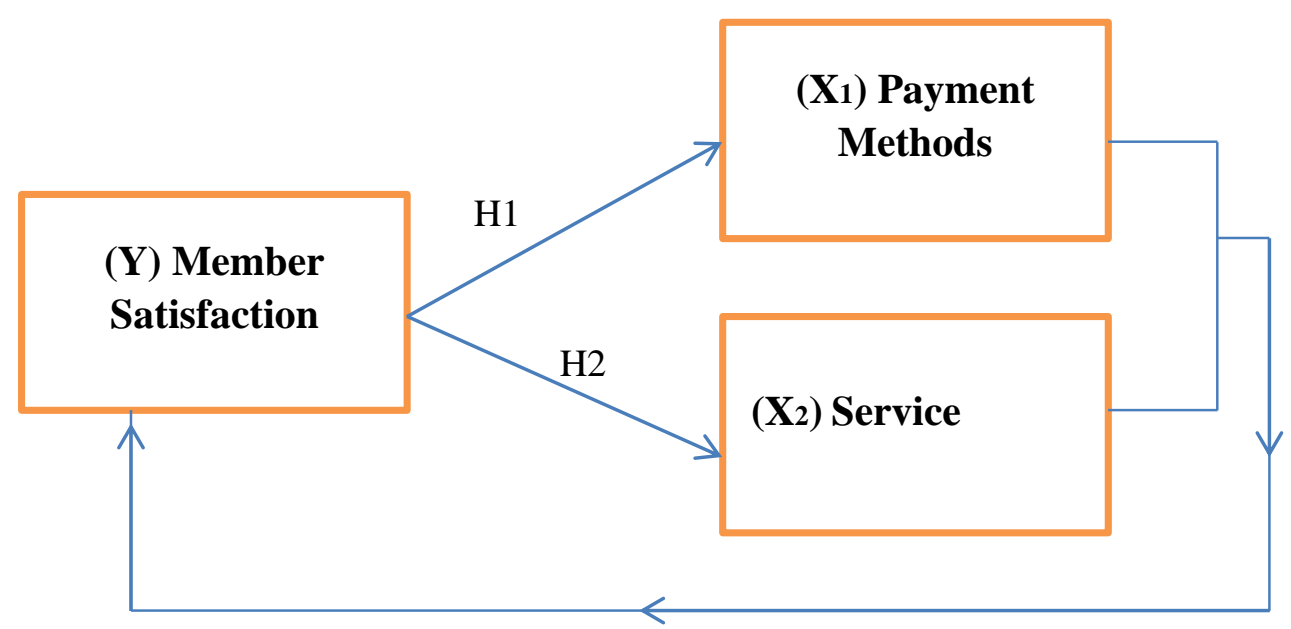

Figure 1. The conceptual framework

\section{RESULTS AND DISCUSSION}

\subsection{Results}

The number of population in this administration is all members of BPJS registered in South Tangerang area. Then the sample taken by the utility here is 60 people. The samples involved here were taken in an Acaka or called random sampling so that researchers could not classify gender based prsentation. Then

from 70 samples are given quetionnares only 60 quetionnares that can be in the data so that only $85.7 \%$ of the samples I can exercised. Here are the results of the data processing of the samples I took that $\mathrm{I}$ show in the partial $\mathrm{T}$ test and simultaneous testing:

Table 1. T test (partial test)

\begin{tabular}{|l|l|l|l|}
\hline \multicolumn{1}{|c|}{ Path } & T & T tabel & Conclusion \\
\hline $\begin{array}{l}\text { Payment Methods } \\
\text { Customer } \rightarrow \\
\text { satisfaction }\end{array}$ & 2.015 & 2.002 & $\begin{array}{l}\text { Significant } \\
\text { (Hypothesis is } \\
\text { accepted) }\end{array}$ \\
\hline $\begin{array}{l}\text { Service Customer } \\
\text { Satisfaction } \\
\text { Payment }\end{array}$ & 2.917 & 2.002 & $\begin{array}{l}\text { Significant } \\
\text { (Hypothesis is } \\
\text { accepted) }\end{array}$ \\
\hline
\end{tabular}

The payment method (X1) obtains the results of a T-test study or partial test can be known T-count $(2,015)>\mathrm{T}$-table $(2,002)$ and SIG values. of $0049<0.05$, thus $\mathrm{Ha}$ accepted. It can be concluded that the payment method is positively influential towards the satisfaction of BPJS members health. Service BPJS
Health (X2) research results above can be known $\mathrm{T}$ - count $(2,917)>\mathrm{T}-$ table $(2,002)$ and sig value. The amount of $0.005<0.05$, thus Ha is acceptable. Then it can be concluded that BPJS health services positively affect the satisfaction of members of BPJS health. 
Table 2. Simultaneous testing $(f)$

\begin{tabular}{|c|c|c|c|}
\hline Path & F & F tabel & Conclusion \\
\hline $\begin{array}{c}\text { Payment methods } \\
\text { and services } \\
\begin{array}{c}\text { customer } \\
\text { satisfaction }\end{array}\end{array}$ & 6,535 & 3,160 & $\begin{array}{c}\text { Significant } \\
\text { (Hypothesis is } \\
\text { accepted) }\end{array}$ \\
\hline
\end{tabular}

From the test result $\mathrm{F}$ that the obtained test result value $f$ indicates the value $F$ count of 6.535 with significance 0.003 . The $F$ value of the table at $\alpha=0.05$ is 3,160 . So, F count (6.535) > F table (3.160), so it can be concluded that the regression model (method of payment and service BPJS Health) together - the same simultaneously affects the satisfaction of BPJS members health.

\subsection{Discussion}

4.2.1. Influence of payment method to the satisfaction of BPJS health members

The payment method variable (X1) has a value of sig. $0.049<0.05$ means significant. So H1 is accepted, meaning payment methods significantly affect the satisfaction of BPJS health members.

From the results of the study that the payment method in paying BPJS dues is already easy, payment of dues BPJS health can be done via bank transfer and can also be done in some mini market, but still many complaints from participants BPJS about frequent problems occur when making payments so as to make the participants BPJS health lazy to pay the dues BPJS health.

If BPJS health method of payment is easy, not often disruptions and available in various payment places and well educated to the public regarding the procedure of payment and place of payment available This will increase the satisfaction of BPJS health members.

\subsubsection{The effect of BPJS health services to the satisfaction of BPJS health members.}

Service Variable BPJS Health (X2) has a value of sig. $0.005<0.05$ means significant. So H2 accepted, meaning BPJS health services affects the satisfaction of BPJS health members. From the results of the research appears that the Ministry of Health Insurance Social Security (BPJS-health) has been good, but still there are some complaints from the community especially participants BPJS-health. One of which is often dissociable when undergoing hospitalization at the hospital sometimessometimes get facilities that do not match the facilities listed on the card, or forced to be treated to a more high class because the room that corresponds to the standard is already full, as a result the patient must increase the cost of treatment or the patient must wait to be hospitalized. In case of hospitalization in the higher class the patient does not get a substitute for the cost of replacement, whereas when undergoing hospitalisation in the lower class the patient is not subject in this case proved in the service of hospital and BPJS services in response to complaints and problems of the public, fast response and in accordance with predefined standards, it will greatly affect the 
increasing satisfaction of members of BPJS Health.

4.2.3. Influence of payment methods and services BPJS Health to satisfaction BPJS health members

Test results $f$ that obtained the test result value $\mathrm{F}$ indicates the value of $\mathrm{F}$ count of 6.535 with significance 0.003 . The value of $F$ table at $\alpha=0.05$ is 3,160 . So, $F$ count (6.535) > F table (3.160), so it can be concluded that the model Regression (Payment methods and services BPJS Healthcare) together - the same simultaneously affects the satisfaction of BPJS members health.

Easy payment method is done by all people and balanced with good service, fast response and completeness of facilities - medical facilities available in every hospital appointed to receive participants BPJS will greatly affect the satisfaction of the members of BPJS health.

\section{REFERENCES}

\section{(2000). Prinsip-Prinsip}

Pemasaran. Jakarta: Erlangga.

(2003). Manajemen

Pemasaran. Jakarta: Indeks Kelompok Gramedia.

Andriyanto, R., Effriyanti, E., \& Hidayat, A. (2018). The Effect of Spiritual Intelligence (SQ) and Personality Types on Auditor's Ability to Detect Fraud. JABI (Jurnal Akuntansi Berkelanjutan Indonesia), 1(3), 258-268.

Aprilianto, B., \& Hidayat, A. (2020). Pengaruh Bisnis E-Commerce dan Pemeriksaan Pajak terhadap Penerimaan Pajak (Studi Kasus Wajib Pajak Yang Terdaftar di KPP Kelapa Gading). EkoPreneur, 1(2), 156168.

\section{CONCLUSION}

Based on the results of the study conducted on 60 respondents it can be drawn conclusions-the following conclusions:

1. Payment method in a partial positive effect on the satisfaction of BPJS Health members in South Tangerang HOSPITAL, therefore H1is accepted.

2. Ministry of BPJS Health has a partial positive effect on the satisfaction of BPJS Health members in South Tangerang HOSPITAL, hence $\mathrm{H} 2$ is received.

3. Payment methods and services BPJS health together - equally positive effect on the satisfaction of BPJS Health members in South Tangerang, hence the $\mathrm{H} 3$ is received.

Azwar, A. (1996). Pengantar Administrasi Kesehatan. Jakarta: Bina Rupa Aksara.

Donnelly, Gibson. (1996) Organisasi, Prilaku, Struktur, Proses. Jakarta: Erlangga

Effendy, O. U. (1989). Kamus Komunikasi.

Bandung:Informatika

Indarjati, A. (2001). Kepuasan Konsumen. Jakarta: Pranata.

Jacobalis, S. (2004). Menjaga Mutu Pelayanan Rumah Sakit. Jakarta: PT. Gramedia.

Kertodipuro, S. (1985). Dasar-dasar Organisasi dan Manajemen. Jakarta: Ghalia Indonesia.

Kotler, P. (1997). Manajemen Pemasaran :Analisis, Perencanaan, Implementasi, dan 
EAJ (Economics and Accounting Journal) - Vol. 3, No. 3, Sept 2020 -Sopiyana

Kontrol. 10 Januari. Jakarta: PT. Prenhallindo.

Kountur, R. (2004). Metode Penelitian. Jakarta: PPM.

Kumar, A (1999). Bank Marketing Mix: New Strategy in Today Banking Sector, BPR Technologia: A Journal of Science, Tehnology \& Management, Volume 2, 2013.

Kurniawan, A. (2005). Transformasi Pelayanan Publik. Yogyakarta: PEMBARUAN.

Mahmudi. (2005). Manajemen Kinerja Sektor Publik. Yogyakarta: UPP AMP YKPN.

Martadisastra, U. (2002). Azas-Azas Manajemen Konsep dan Aplikasinya. Bandung: Dinamika.

Moenir, H.A.S. (2006). Manajemen Pelayanan Umum di Indonesia. Jakarta: Bumi Aksara.

Morgan, C, T., King, R, A., Robinson, N, M. (2001). Pengantar Psikologi. Jakarta: International Book Company.

Muljono, T. P. (2001). Manajemen Perkreditan Bagi Bank Komersil. Yogyakarta: BPFE.

Siagian, S. (1995). Teori Motivasi dan Aplikasinya. Jakarta: PT. Rineka Cipta.

Sugiyono. (2011). Metode Penelitian Kuantitatif Kualitatif. Bandung: Alfabeta.

Suryawati, D., Shaluhiyah. (2006). Penyusunan Indikator Kepuasan Pasien Rawat Inap Rumah Sakit Di Provinsi Jawa Tengah. Jurnal manajemen Pelayanan Kesehatan, 09, 177-184.

Sutanta. (2003). E-Government. Jakarta: Erlangga

Sutarbi, T. (2005). Sistem Informasi Manajemen. Yogyakarta: ANDI.

Suwatno. (2001). Asas-Asas Manajemen Sumber Daya Manusia. Bandung: Suci Press.

Suyani, N. (2018). Effect Of Brand Equity And Marketing Mix On
Customer Satisfaction And Impact On Customer Loyalty, EAJ (Economics and Accounting Journal) Vol 3, No 1 (2020)

Tjiptono, F. (1997). Prinsip-Prinsip Total Quality Service. Yogyakarta: Andi Offset.

Wahyono, T. (2004). Sistem Informasi Konsep Dasar, Analisis Desain dan Implementasi. Yogyakarta: GRAHA ILMU.

Zahnd, M. (2006). Perancangan Kota Secara Terpadu. Yogyakarta: Kanisius. 